and Europe. However, in contrast to these adjacent regions, Greenland is relatively unexplored from a mineral resource point of view and it can be claimed that the island is the northern hemisphere's last main frontier. The common conception that Greenland is remote and inaccessible is presumably responsible for the low level of exploration activity. The impression of remoteness was perhaps true in the 1950s and 1960s; it is far less true today where an efficient logistic system exists based on sea and air transport. The exploration infrastructure in terms of geological data has also been significantly advanced in the past 30 years and has in turn led to a better understanding of Greenland's geological provinces and to a higher level of metallogenetic interpretation.

The promising mineral potential of Greenland is shown by the exploitation of metallic and industrial minerals already carried out. The cryolite open-pit at Ivittuut and the lead-zinc mines of Blyklippen and Black Angel also drew attention to the feasibility of mining in Greenland's arctic conditions, as well as adaptation to technically difficult local physiography. A number of deposits have been drilled. Those with large mineable reserves have not yet gone into production; low market prices are not balanced by the high starting and transport costs. One example is Malmbjerg, impractically situated between two glaciers in the mountainous terrain of East Greenland (see photograph in Dawes et al., this report) where 150 million tons of molybdenite ore documented decades ago remain unexploited. Seen in relation to the geology of Canada and Europe and to the mining industry of these regions, the odds are that Greenland's promising potential will eventually be realised by new discoveries of economically viable deposits.

H. K. S. \& P. R. D., Geological Survey of Greenland, Copenhagen.

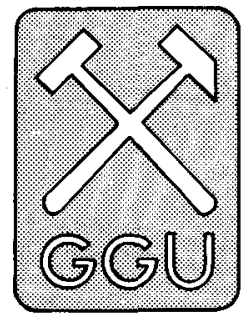

\title{
Greenland MINEX News: a new service for the mining industry
}

\author{
Peter R. Dawes and Henrik Højmark Thomsen
}

In the last few years there has been increased political awareness of the urgency to ensure the continuing and long-term involvement of the mining industry in Greenland's economy. Formalisation of this came in 1990 when an ad hoc working group was convened by the Danish Ministry of Energy and the Chairman of the Greenland Home Rule Authority with the purpose of working out a draft for a new strategy for exploration and utilisation of mineral resources in Greenland. The report containing specific recommendations was released the same year, the text being made available in Danish, English and Greenlandic (MRA, 1990).
In response to these recommendations, the Geological Survey of Greenland (GGU) was involved in a number of activities designed to improve the channelling of geological data from Greenland to international industry. An immediate move was the introduction of a new information service that started with a newsletter directed primarily to the oil industry. The newsletter, called GHEXIS (Greenland Hydrocarbon EXploration Information Service), was distributed for the first time in the fall of 1990 (Pulvertaft, 1991).

On the 'hard mineral' side, the past year saw a number of initiatives to structure information and improve 


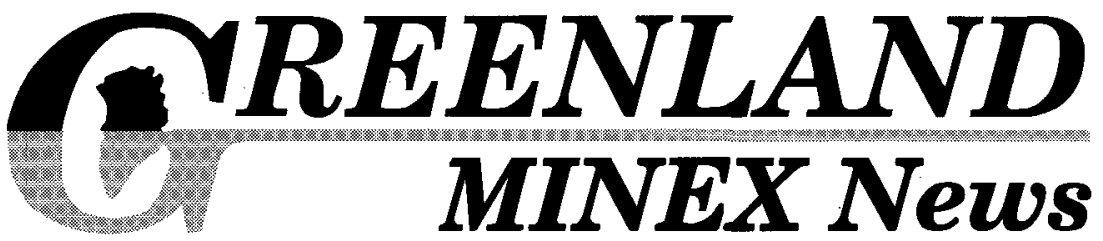

Fig. 1. Greenland MINEX News; first issue was distributed in 1992 .

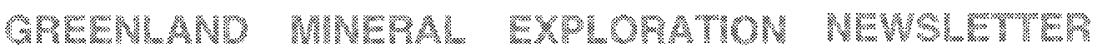

its flow to the mining industry, both geoscientific and exploratory data from GGU, and legislatory and licensing information from The Mineral Resources Administration for Greenland (MRA). One such initiative was an information campaign carried out in North America and Europe and reported on elsewhere in this Report of Activities (Dawes et al.); another was the initiation of a companion newsletter to GHEXIS, aimed at the mining industry. This newsletter is called Greenland MINEX News (Greenland MINeral EXploration Newsletter) with the first issue sent out in July 1992. This note briefly describes MINEX and its main aims.

Greenland MINEX News is issued by GGU and MRA. It is planned as a bi-annual service providing a wide range of exploration-relevant information from pure geological data and assessments to licensing and regulatory material. Geological emphasis will be placed on new studies either in progress or at the planning stage, and on data now available to industry, either in the form of published reports, bulletins and maps or as unpublished material in GGU's data base and archives. The latter category of information - unpublished - is often particularly relevant to mining companies interested in operating in Greenland, and pne of the aims of MINEX is to bring to the attention of the mining sector the nature and scope of information on site in Copenhagen and available on request. For example it is not often appreciated that GGU's map and photograph library contains a wealth of maps, annotated aerial photographs and satellite images from all regions of Greenland, including over 5000 detailed geological field maps that form the basis of regional compilations including the published geological map sheets at scales of 1:100 000 and 1:500 000 .

In short, Greenland MINEX News intends to provide a quick up-date of geological and legislatory information, as well as reports on GGU's data service, sent free to all interested parties. It is planned to be issued as new developments take place or as relevant geological information becomes available. The first issue of the newsletter together with a questionnaire was sent out to all companies and individuals known to have an interest in the mineral exploration of Greenland. The response has been good, and the 200 or so companies on the mailing list at the end of 1992 will receive future issues of the newsletter. The second issue was distributed in March 1993. To illustrate the type of information to be dealt with by MINEX, the following excerpts are condensed from the first issue.

\section{Geological and exploration briefs}

Greenland diamonds. The fever created by the recent Lac de Gras diamondiferous kimberlite discovery in the North-West Territories of Canada, has been felt in Copenhagen. This discovery, one of the largest ever exploration plays in Canada, has resulted in a marked interest shown by commercial companies in Greenland occurrences. Diamondiferous kimberlites are restricted to the world's ancient stable cratons and, favourably, Greenland exposes such blocks. The West Greenland block in particular has been mapped in detail, and kimberlites, lamproites and related rocks have been recorded. All information related to potentially diamondiferous rocks in West Greenland has been compiled into an Open File report that describes and gives exact locations of nearly 500 occurrences (Larsen, 1991).

New gold exploration target. A new gold mineralisation was discovered by GGU in summer 1991 during regional geological and geochemical mapping on Nuussuaq in the Disko Bugt area of central West Greenland $\left(70^{\circ} \mathrm{N}\right)$. It is hosted in a Precambrian greenstone belt, more specifically in a metachert along with disseminated sulphides. The metachert is deemed to have an exhalative origin with deposition on the ocean-floor during mafic-ultramafic volcanism. The mineralisation has been described in an Open File report (Thomassen \& Tukiainen, 1992).

1992 exploration - a push to the world's top. In 1992 exploration by mining companies was carried out on all sides of Greenland. The traditional regions for mineral exploration, those of western, eastern and southern 
Greenland, were joined in 1992 by activities in northern Greenland as far north as $83^{\circ} \mathrm{N}$ (Platinova $\mathrm{A} / \mathrm{S}$ and Nanisivik Mines Ltd), marking a resoluteness to extend the search for economic minerals to the world's northernmost territories.

\section{Regulatory and licensing information}

New licences. Twenty new exploration licences regarding minerals have been granted for the 5-year period 1992-96.

Favourable taxation rules. In spring 1992 several particularly favourable rules concerning mineral resources activities were adopted.

\section{References}

Larsen, L. M. 1991: Occurrences of kimberlite, lamproite and ultramafic lamprophyre in Greenland. Open File Ser. Grønlands geol. Unders. 91/2, $36 \mathrm{pp}$.

MRA, 1990: Report from The Strategy Group for Mineral Resources in Greenland, 76 pp. Copenhagen: Mineral Resources Administration for Greenland.

Pulvertaft, T. C. R. 1991: 1990 - a year of change in hydrocarbon-geological activities at the Geological Survey of Greenland. Rapp. Gronlands geol. Unders. 152, 11-13.

Thomassen, B. \& Tukiainen, T. 1992: Gold mineralisation in Precambrian supracrustal rocks on southern Nuussuaq, central West Greenland: 1991 results. Open File Ser. Grønlands geol. Unders. 92/3, 31 pp.

P. R. D. \& H. H. T., Geological Survey of Greenland, Copenhagen.

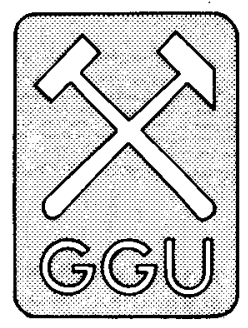

\title{
Greenland mineral resource information to industry: increased scope in 1992
}

\author{
Peter R. Dawes, Hans K. Schønwandt \\ and Bjørn Thomassen
}

The year 1992 has seen an expansion in the scope of the Geological Survey of Greenland's (GGU) information service to the mining industry. In the preceding few years this part of GGU's work has been improved by a number of facilities, ranging from the establishment in Copenhagen of a Mineralisation Data Bank and Core Library to a new publication policy aimed at streamlining the processing time and availability of in-house geological data, as well as ensuring improved public access to released company data stemming from concessionary exploration work in Greenland (see Ghisler 1990, 1992; Schønwandt, 1991). A more recent venture has been the introduction of a newsletter - reported on elsewhere in this report (Dawes \& Thomsen).
The widening in scope of GGU's information service is led by two broad initiatives launched in collaboration with the Mineral Resources Administration for Greenland (MRA); both are designed to promote international interest in the mineral potential of Greenland and both involve presentation of geological data at venues away from headquarters in Copenhagen. The first, a promotion campaign in North America and Europe, provides an on-the-spot service to international exploration and mining audiences; the second took the form in 1992 of an open excursion to mineralisation showings in part of East Greenland, arranged to give potential investors first-hand knowledge of the island's economic geology, logistics and field conditions. 